Volume 5, Issue 1 (2016) 33-53 | Published online, 27 February 2017

The publication of the JEOD is supported by the Autonomous Province of Trento, Italy

\section{AUTHOR}

PAOLA RAFFAELLI

University of Roehampton

raffaelp@roehampton.ac.uk

\title{
Social and Solidarity Economy in a Neoliberal Context: Transformative or Palliative? The Case of an Argentinean Worker Cooperative
}

\section{ABSTRACT}

Neoliberalisation process was imposed worldwide and it made many grassroots responses emerge, which many can be conceptualised as part of the Social and Solidarity Economy (SSE). Within this field, worker co-operatives appear as an option to mainly safeguard employment and earn a living. Several cases have been documented about worker co-operatives as a way to develop impoverished areas or vulnerable populations. However, co-operatives in many cases appear as a second best employment option during turmoil, rather than as an alternative to mainstream economy, which ultimately is the cause of poverty and vulnerability. This paper seeks to widen social economic literature and explores the tension inherent in the concept of SSE, namely whether it should be seen as an alternative to capitalism or a means of ameliorating its worst effects. Although this tension has been minimised in the literature, by introducing the case of an Argentine workers' cooperative, this research illustrates how these two antagonistic discourses coexist within the organisation.

\section{KEY-WORDS}

SOCIAL AND SOLIDARITY ECONOMY; WORKER COOPERATIVES; WORKER-RECUPERATED ENTERPRISES; LABOUR MOVEMENTS; ARGENTINA

JEL Classification: B5; J01; J50; J54; J58; Z13 | DOI: http://dx.doi.org/10.5947/jeod.2016.003

\begin{abstract}
Acknowledgments
This research is based on my PhD studies. I would like to express my thanks for the scholarships received by the University of Roehampton (London, UK) and to my supervisors Molly Scott Cato and Steven Howlett, without their support this article would not have been concluded. I am also very thankful to all the members of C-coop-Arg who accepted to participate in this research; with those who attended my presentation at the International Co-operative Alliance Research Conference held in Antalya, Turkey in November 2015, and to my colleague Gabriela Thompson. Finally, I would like to express my thanks to the European Research Institute on Co-operative and Social Enterprises for hosting me during the time I wrote this paper, and particularly for the invaluable comments made by Carlo Borzaga and Marcelo Vieta that helped to improve this article enormously, and to JEOD editors for their helpful guidance.
\end{abstract}




\section{Introduction}

Market liberalisation and deregulation policies have been homogeneously implemented worldwide as a result of the universal adoption of the neoliberal doctrine over the past three decades. These measures—although diverse in their intensity—were similarly implemented and designed in developed and developing countries with disregard for historical particularities (Mano, Raffaelli and Souza, 2016); and market rationality was presented as the readily available answer for economic misbalances all across the world (Brenner, Peck and Theodore, 2010). However, neoliberal doctrine has been found to have a number of limitations, in particular its inability to sustain the wage labour system (Dinerstein and Neary, 2002), as well as its clear anti-labour policies and union-busting strategies. The result of this has been a deterioration in living conditions (UN, 2006). In response to economic, political and socio-cultural restructuring, social actors engaged in collective actions that sought to reduce poverty and exclusion, as well as to achieve social transformation. These responses took different forms including charities, social enterprises, barter organisations, worker cooperatives, informal organisations of the self-employed and alternative forms of unions, etc. This range of organisations are generally identified under the umbrella of the Social and Solidarity Economy (SSE).

However, not all of the SSE organisations are alternatives to market economy nor do they all provide welfare. Drawing upon these threads, this paper explores the disagreements and tensions in the field of SSE from a critical discourse perspective, exploring the multifarious forms that this impulse towards "humanising the economy" (Restakis, 2010) has taken in Argentina. This addresses the unresolved paradox of SSE, namely, to what extent it should be seen as an alternative to capitalism or a means of ameliorating its worst effects, both in social and economic terms. Thus, within the literature, it is possible to identify two opposite conceptualisations of the SSE: as a bridge through which excluded people could be included back in the economic system (Nyssens, 2006); or as an alternative form to the market economy (Coraggio, 2010; Laville, 2013). Particularly, the focus of this research is worker co-operatives, of which similarly diverted conceptualisations have been formulated. Very radical examples appeared as a response to neoliberalisation, such as workerrecuperated enterprises (empresas recuperadas por sus trabajadores, ERTs) (Ruggeri and Vieta, 2015), whereas other business-oriented trends were also identified recently (Lima, 2004; Ruggeri, 2011).

In this paper, I take the route of exposing and dissecting the tensions recognised in the literature. The objective of identifying these contradictory discourses is to expose the power relations that SSE, particularly worker co-operatives, are part of. Moreover, it will also answer to what extent their role is based on their own principles or whether they respond to other sectors' interests that are often compromised by the market and state. Therefore, from an SSE point of view, it is important to acknowledge these structural limitations in order to develop strategies to protect SSE and worker co-operatives against external interest in shifting SSE's values. This is done through the use of Critical Discourse Analysis (CDA), which allows us to be both critical and to uncover power structures. Defined in detail shortly, this is ultimately a poststructuralist approach, since this theory 
provides the researcher with the theoretical tools to conduct such a dissection. Also, it proposes the idea of destabilising hierarchies of meanings, categorisations and classifications in order to challenge assumptions (Belsey, 2002). Furthermore, poststructuralism proposes the analysis of social elements and their systematic relations, rather than analysing them in isolation (Jørgensen and Phillips, 2002).

In particular, this paper focuses on a printing worker co-operative in Argentina, C-coop-Arg ${ }^{1}$, and explores the palliative and alternative tensions reflected above as suggested by this case study. C-coop-Arg's relationship with government is an expression of the alleviative role of co-operatives within a market economy. Contrarily, the cooperative members' decision in taking part in a co-operative is a clear example of their positioning as a radical alternative. Additionally, the cooperative appears as a means of providing its members with job opportunities based on a radically different management. The paper is structured in five sections. Section 2 presents the division in the literature with regard to SSE and co-operatives. Section 3 provides a critical historical account of co-operative movement in Argentina, to understand the links between the sector and the state. Section 4 presents the methodology and justification for methodological decisions. Findings are reported in Section 5, pointing out the tension between the palliative and alternative discourses, along with structural constraints for co-operatives. Section 6 concludes the paper with a discussion and some insights for future research.

\section{Tensions within Social and Solidarity Economy}

Broadly speaking, SSE is a sector of the economy that "organises economic functions primarily according to principles of democratic co-operation and reciprocity; guarantees a high level of equality and distribution, and organising redistribution when needed; and satisfies human basic needs, in a sustainable way" (Moulaert and Nussbaumer, 2005: 2079). Moreover, organisations have social objectives and, although they may engage in some market activity, the economic imperative does not prevail over the social objectives of the organisation. Therefore, what defines SSE is its own rationality, which is distinct from that of the market economy and government sectors; namely social justice, competence and redistribution respectively (Moulaert and Ailenei, 2005). These three different-even opposed — rationalities tell these three sectors apart. Particularly, SSE rationality draws on forms of exchange that take into account social justice and equality through relationships based on cooperation and association (Moulaert and Ailenei, 2005).

The Social Economy is defined by Coraggio (2010) as an economic sector that re-signifies commodification and marketisation of labour, land and capital, in order to propose transformative

In general, case studies are anonymised in the United Kingdom. As this is part of a PhD thesis at University of Roehampton, I decided to anonymised it as well. 
economic actions in the pursuit of a different economic system. It is widely accepted that the social economy is made up of cooperatives, mutuals, and organisations (Coraggio, 2007; Gibson-Graham, 2008; Utting, 2015). The conceptualisation of social economy was enlarged and strengthened in light of the differences of the sector in different places. In this sense, the concept of Social and Solidarity Economy (SSE) was coined highlighting the significance of people and their work in the economy (Razeto, 1984; Eme and Laville, 2004). Moreover, it suggests the need for a system transformation taking into account redistributive justice, sustainability, and participatory democracy (Utting, 2015). In this perspective, self-managed work is central, as it acknowledges employment inclusion in the capitalist market is no longer an option for large sectors of the population (Coraggio, 2010). Given the aim of this paper, the concept of the SSE is relevant for the analysis of worker cooperatives.

The concept of SSE was neither stable across time nor agreed between countries (Laville, Young and Eynaud, 2015). The importance of the SSE organisations has increased in recent years as the government support they have received in many countries such as Argentina, Brazil, Venezuela, Ecuador and Bolivia (Coraggio, 2011; Giovannini and Vieta, fortchcoming). The range of forms in which SSE has been included in public policies illustrates the differences in the understanding of the sector. The case in Brazil was understood as a co-construction of policies linked with the SSE, whereas in Argentina it responded to the populist model of state, and in Ecuador the SSE system was organised under the premise of Buen Vivir (Coraggio, 2015). However, government support has raised suspicion among scholars. In Latin America, some scholars have voiced their concerns about these policies, condemning them as a strategy for the institutionalisation of collective action (Dinerstein, 2007) and limiting autonomy and independence (Ruggeri and Vieta, 2015).

Theorisations of SSE share the idea that it is the impulse of association which lies behind these organisations. SSE relies on an autonomous social process in which cooperation, reciprocity, trust and plurality take a central place (Albuquerque, 2004a; 2004b). It appears as a collective response to intolerable situations which the dominant economic structure is unable to solve (Coraggio, 2004). Shared values create solidarity between organisations; trust and reciprocity is built up into cooperation and collaboration, which becomes the basis of formal and informal networks (Pearce, 2005). In general, SSE in Argentina emerged bottom-up as a popular response to economic limitations. They occupied counter-hegemonic spaces resisting political domination and economic marketisation. Thus, SSE is part of a power struggle in which market and state imperatives often compromise these ideals. Therefore, it is important to examine whether the SSE sector can struggle or protect against these various tendencies that jeopardise SSE values.

Importantly, a study of the literature demonstrates that the vision of the role of SSE often glosses over an important dichotomy regarding its alleviative or transformative role (McMurtry, 2004; 2009). On the one hand, some authors have emphasised the importance of the increasing interdependence between the private and public sectors in the provision of social services (Kaufmann, 1991). This is the case with many organisations reliant on public funding or donations that aim to improve human well-being (Nickel and Eikenberry, 2010), and that minimise the effects of 
globalisation (Brooks et al., 2009). Governments in many countries have recognised and supported SSE organisations as partners in welfare provision, and created social acceptance for the involvement of extra-state organisations in the delivery of public services (Anheier, 2004). Moreover, the role of SSE in tackling poverty was recognised (Nyssens, 2006). This would suggest a change both in government and SSE organisations' roles, as the public policy sphere was previously dominated by the state during the welfare regime.

On the other hand, scholars have also suggested the idea that SSE is an alternative for a different economic development, which takes into account individuals, families and communities and produces society along with economic utilities (Coraggio, 2002). Another crucial element in the construction of the plural economy is the reinsertion of democracy into economic life (Laville, 2013). Following these lines, Amin, Cameron and Hudson (2002) consider the prime interest of SSE is building social capacity, covering under-met needs and, through this process, creating new forms of work. Thus, production of goods is not what makes SSE stand apart, but rather the way they organise and manage this production (Molloy et al., 1999). Although this trend recognises different rationalities between SSE and the market economy, it acknowledges that SSE organisations might be run as successful businesses, albeit with its prime interest in social construction (Amin, Cameron and Hudson, 2002).

SSE has been identified by many governments as a sector that might offer solutions due to its presence in three key sectors: welfare services, work integration and local development (Spear, 2005). In this context, the importance of SSE grassroots experiences for the regeneration of social ties was recognised (Aiken, 2006), particularly with a view to tackling structural unemployment and exclusion in a context of state and market restriction (Nyssens, 2006). This consequently showed that these organisations could work as substitutes for the state (Kendall, 2005). In order to provide welfare services, SSE appeared as a more direct option when compared to the state due to their local articulation, interpreting directly the needs of the communities and reducing the enormous state apparatus, bureaucracy and intermediaries (Smith, 2010; Murray, 2013).

As was said, it is widely accepted that cooperatives, mutuals, and organisations make up the SSE (Coraggio, 2007; Gibson-Graham, 2008; Utting, 2015). Although many traditional Marxist theorists have discredited the emancipatory potential of worker cooperatives, as shown by Atzeni and Ghigliani (2007), this is not the case with this research. Within an economic perspective that proposes a transformation of the economic structure in pursuit of redistributive justice (Coraggio, 2010), sustainability, and participatory democracy (Utting, 2015), the analysis of worker cooperatives can shed light on an important sector of the SSE. Furthermore, as inclusion in the market through employment has shown limitations, making alternative forms of employment visible can contribute to the enlargement of counter-hegemonic practices. Particularly, worker cooperatives are based on the values of self-management, democratic decision-making, solidarity, and production of goods taking people into consideration (ICA, 1995). Therefore, worker co-ops can be conceptualised within the SSE, and some insights of the transformation that the market has provoked in its values will be outlined in the following sections. 
Particularly, worker co-ops rely on the principle of work as a creative and productive activity and aim to oppose the alienation, profit-driven and deskilling process that capitalist organisations impose on workers (Atzeni and Vieta, 2014). They have a main social purpose of safeguarding employment (Pearce, 2005), which may be accompanied by others, such as minimising environmental damage, benefiting the local community, or enhancing SSE in general. However, cooperatives in many cases appear as a second best employment option during turmoil (Salamon and Anheier, 1997), rather than as an alternative to mainstream economy, which ultimately is the cause of poverty and vulnerability. Additionally, the use of the legal cooperative form has also served market purposes. Business-oriented cooperatives have the purpose of lowering production costs via outsourcing. This strategy was used for both private and public sectors and has been documented in Argentina (Ruggeri, 2011) and Brazil (Lima, 2004). Rather than representing cooperative radical values, business-oriented organisations expose the intention of neoliberal discourse to colonise counterhegemonic practices.

A large amount of literature in the field of cooperatives describes their role in reducing poverty and minimising the direct impacts of neoliberalism; mainly regarding agricultural cooperatives in developing countries (Allahdadi, 2011; Benson, 2014). Moreover, disadvantaged groups have formed cooperatives as a solution both for generating income and empowerment. Some examples are the case of women in a small village in Uganda (Dol and Odame, 2013), autonomous waste pickers who improved their working conditions by forming a cooperative in Argentina (Maldovan, 2014), or unemployed people who decided to set up a cooperative in order to preserve their living conditions (Ranis, 2010; Dinerstein, 2007). These activities were conceptualised as work integration, whose main aim was "to help disadvantaged unemployed people, who are at risk of permanent exclusion from the labour market" (Nyssens, 2006:13).

Although cooperatives are an efficient tool that belong to worker's social capital in response to tough situations (Raffaelli, 2013), it is important to contrast endogenous worker's experiences from those that only see cooperation as a second best employment option. As presented, SSE is a field of disagreement and tension in a variety of forms. This leads to a question regarding the role of SSE and worker cooperatives; are they an alternative to the market system or are confined to ameliorating the worst effects of neoliberal policies? After having presented the SSE theoretically, we will move into the particularities of our case, exploring how the SSE and the cooperative movement was structured in Argentina.

\section{Historical background and the role of cooperatives in Argentinean history}

Argentinean SSE emerged in parallel with the formation of the working class at the end of 19th century. Both social processes were shaped by the international migration that the country received mainly from Spain and Italy, the majority being workers involved with communist and socialist movements and unions (Schujman, 1984; Arzadun, 2011). It is widely accepted in the literature 
that mutuals and mutual aid societies, benevolent societies, and renters' associations responded better to the urban workers' needs, whereas Argentina's first cooperatives initially emerged as a way to cope with larger, more powerful companies by small farmers (Schujman, 1984; Campetella, González Bombal and Roitter 2000; Ressel and Silva, 2008; Teitelbaum, 2011; Giovannini and Vieta, forthcoming). During the first half of the 20th century, the Argentine cooperative movement increased significantly (Montes and Ressel, 2003). In general, it was a strategy adopted by those who needed to solve immediate problems through collective action, solidarity and demands for socio-economic inclusion, aiming to reduce economic concentration and, to some extent, issues of work as counterpoints to the economic struggle (Schujman, 1984). In other words, people experiencing tough living conditions organised collectively through solidarity ties, sought not only to solve problems but also to attain social recognition.

The rise of Juan Domingo Perón in 1946 was a turning point in Argentine society (Adelman, 1992) due to the social transformations Peronism provoked, bringing the working class to the centre of the political arena (Murmis and Portantiero, 2004). During this era, SSE was conceptualised as part of a much broader project, known as justicialismo, in which the idea of a third way refers to Peron's personal vision of politics, as neither capitalism nor communism (Vieta, 2012). Nonetheless, what is a matter of fact is that support for rural and consumer cooperatives were included in the two five-year economic plans in 1946 and 1952 (Levín and Verbeke, 1997), but as a means to alleviate social needs for working people rather than an explicit backing of the SSE. As a consequence, co-ops almost quadrupled between 1940 and 1955 (Arzadun, 2011). This enlargement of SSE was part of a process of consolidation of working class institutions and the establishment of the local welfare state. Although Peronism encouraged cooperative formation, it merged them with the state sphere, which constrained their independence. Consequently, the SSE began to be mobilised by the state to provide response to the demands of the lowest income sectors of society alongside a consolidation of power (Coraggio, 2002). Although this procedure was not constant and there are historical periods when SSE acted independently, Argentina is considered a populist ${ }^{2}$ example of the emergence of the SSE sector (Coraggio, 2011).

In spite of the quantitative increase the cooperative movement has accounted for during the 20th century, by the end of the century it experienced a dramatic qualitative change as a result of the neoliberal crisis. Whereas in the beginning of the century cooperatives were in relation with agricultural production, they shifted to public services in the middle of the century, and in the 2000s they were mainly worker cooperatives, due to the employment issues of the neoliberal regime (Arzadun, 2011). Additionally, many co-ops became highly bureaucratic and lacking in principles (Coraggio, 2011). In some cases, the use of the cooperative form was distorted by what have been known as "false cooperatives" formed to avoid taxes and create further precarious (and cheaper)

\footnotetext{
2 Populism is a leadership style characterised by a strong leader who links himself straight with the masses rather than through institutions, provoking their weakening (Conniff, 2012).
} 
work relationships. The result was that, by the end of the 20th century, anarchist and socialist cooperative principles did not stand the test of time (Ruggeri, 2011). Despite the discrediting of the sector in the wake of the biggest social-economic and political crisis in Argentina by the end of 2001, when unemployment rate stood at 25 per cent and poverty at 45 per cent, (Lindemboin, Graña and Kennedy, 2005; Beccaria and Mauricio, 2005) many collective actions and new social movement actors emerged.

An emblematic case in the analysis of cooperatives in Argentina is worker-recuperated enterprises (empresas recuperadas por sus trabajadores, ERTs). Although the case of this study is not on ERTs, an understanding of them is required for a comprehensive analysis of the sector as they have transformed significantly the Argentinean cooperative movement. Furthermore, the origin of C-coop-Arg was inspired by the process of ERTs and therefore presents some similarities. Workers, facing closing workplaces and owners' neglect for remedial action in the face of micro- and macroeconomic failure, decided to occupy their workplaces and make them productive again (Saavedra, 2003; Rebón and Caruso, 2004; Fontela, 2008; Ruggeri, 2011; Cvejic and Petrovic, 2015; Vieta 2013; Ruggeri and Vieta, 2015). In this sense, workers soon understood that their best chances of tackling the growing crisis was from within the workplace, rather than accepting their redundancies passively (Raffaelli, 2013). ERTs proposed a trade-off between a defensive element that prevented them from losing their jobs, along with a political feature that proposed the idea of autonomy (Dinerstein, 2007). The combination of these two elements is the reason why, despite the fact that the economic situation has improved significantly in the last decade, recuperation of enterprises is not a finished process, but still ongoing, and one that has been reproduced in other countries (Ruggeri and Vieta, 2015).

The irruption of ERTs made the cooperative movement recover the sense that it provides a solution for an employment crisis, as well as a collective answer for regenerating social bonds; the role of the movement became thriving for both social and economic transformation. However, for members of cooperatives, social and economic dimensions are not easy to set apart, possibly due to the circumstances in which the sector reappeared a decade ago. The presence of these two strong standpoints takes some cooperatives to the end of the road, leading many to dissolution due to poor economic results. In a context of both economic and social crisis, SSE proposed another way of organising the economy and of social inclusion (Wyczykier, 2007). An example of this is how ERTs run other types of satellite-projects alongside the worker cooperative, such as popular schools or cultural centres.

Solidarity was instrumental in workers' projects of taking over enterprises and cooperative formations, which is widely recognised in the literature (North and Huber, 2004); however, only a few studies recognise the role of cooperation (Vieta, 2014). In many cases, the legal cooperative form was only a formality; however, the process of consolidation of the company and construction of a social group led members to fully adopt the cooperative principles (Raffaelli, 2013; Vieta, 2014). In this sense, the development of solidarity, the collective form of self-management and the cooperative relationships are a consequence of practical needs rather than ideology (Dinerstein, 
2007). Although this form of cooperative collective response had already appeared in Argentinean history during economic turmoil (Dinerstein, 2007; Wyczykier, 2007), the particularity of the process of cooperative formation in the 2000s was given by the way in which workers managed the failure of neoliberalism (Ruggeri and Vieta, 2015).

The Kirchner era ${ }^{3}$, in an attempt to reduce the unemployment rate, supported financially and politically SSE and social movements via public policies (Dinerstein, forthcoming). The scope was significantly broader as it included ERTs, already conformed co-ops and new co-ops to be founded for participating in those programs. For instance, the self-managed work programme Manos a la obra and the Argentina Trabaja plans sought social inclusion through productive ventures based on associative and self-managed values (Villar, 2004; Dinerstein, 2007; Neffa, Brown and López, 2012). These policies focusing on SSE made the number of cooperatives increase nine times in the decade 2001-2010 (Arzadun, 2011), out of which more than 7,300 were worker cooperatives (Vuotto, 2012). Moreover, the Microcredit programme, which will be referred back to in the findings, was focused on supporting small businesses and articulating them with the economic structure (Foschiatto and Stumpo, 2006). Although these policies were alternatives to the mainstream economic approach, the strength of top-down initiatives is uncertain as they vanished their radical aspect in exchange for economic and technical assistance (Dinerstein, 2007), which leaves cooperatives vulnerable to political decisions. Moreover, these policies were funded by the Ministry of Social Development, historically linked with social assistance, rather than productive funding (Hopp, 2011). Finally, the aim of creating cooperatives was to solve employment issues, which ultimately seeks to enhance market inclusion, rather than being an element of liberation.

More critical authors understand these policies were an example of the populist feature of SSE sector, which does not engender autonomous solidarity, but provides a shortcut to develop public policies in the pursuit of gaining elections (Coraggio, 2011). These policies were a form of social assistance that created further dependency from central government (Ruggeri and Vieta, 2015) or a way of institutionalising social mobilisation. According to Dinerstein (2007), the inclusion of SSE organisations under public policies has implied a resignation of SSE's objectives of solidarity, autonomy and self-management in exchange for state funding and technical support. This understanding of SSE is in stark contrast with the one proposed by Coraggio (2002), who considers that SSE should be recognised as a fundamental part of the economy in developing countries due to the large significance of the informal sector in the satisfaction of needs, which gives as a result a three-sector mixed economy made up of private, public and SSE sectors. Having presented the peculiarities of worker cooperatives in Argentina, the analysis of the existing discourses within them is followed.

\footnotetext{
3 Nestor Kircher was in office from 2003 until 2007. He was followed by his wife, Cristina Fernandez de Kirchner, for two periods: 2007-2011 and 2011-2015.
} 


\section{Methodology}

Based on the idea that "another economy is possible", this research discredits essentialist understandings of reality. Therefore, within the broad range of poststructuralism, Critical Discourse Analysis (CDA) proposes a critical approach to a socially constructed reality in order to uncover the power relations that support social structures. Discourses reproduce social domination and CDA investigates critically the way in which social inequality is expressed, constituted and legitimised through discourse (Wodak and Meyer, 2009). The selection of CDA as the research paradigm allows the uncovering of power relations and situates counter-hegemonic practices; it challenges the taken-for-granted understanding of neoliberalism and the production of counter-hegemonic discourses. Thus, through the discourse of the co-ops members, this study engages in an analysis of the role of cooperatives within the neoliberal regime in respect to their consideration of their actions as palliative or alternative to neoliberalism. In this sense, this paper does not intend to propose a fixed definition of the role of co-ops that can be used universally, as this neglects the historical configurations social processes have. Rather, a holistic interpretation is developed in order to embed the history and culture within the definition.

Interviews were treated as pieces of discourse, in which contradictions in the means of representations, social relations and identities were sought, which are a consequence of the clash of SSE and neoliberal rationalities. Within the social practice of co-ops, differences and diversities in discourses are considered mainly around the contradiction of these two poles, which are linked with the history and structural configuration of cooperatives. These differences and diversities are also present on the empirical level, as representations are a re-contextualisation of a social practice that takes into account internal and external constrictions. Inculcation is the process that takes places when hegemonic struggle between the two competing discourses occurs (Fairclough, 2003). As a result, I looked for the inculcations of neoliberal discourse in the SSE practice. In this sense, CDA will allow me to answer whether worker cooperatives are a palliative to the existing economic system or an alternative economy and to move further on in this theorisation.

The organisation was selected based on my own contacts I had established before (Raffaelli, 2013), and over the base of an exchange relationship (Shenton and Hayter, 2004). A first interview with one of its most longstanding members was conducted, as well as informal conversations with others, which helped me to gain the trust of the rest of the members. For this, my knowledge in the field was vital for helping to build trustable relations, which were instrumental for conducting the research. The study is focused on one worker co-op located in Buenos Aires metropolitan area. To conduct this research, a quasi-ethnographic approach was taken, and two weeks were spent in the organisation. This resulted in over 40 hours of non-participant observation of their work routine; this data was reflected in field notes and helped me to build up the unstructured interview guide. Data gathered throughout interviews and observation provided me complementary information of the cooperative practice, and allowed me the triangulation of the information (Jick, 1979). Interviews were done on the basis of three areas of interest with respect to the role of worker co-ops. First, I questioned their current understanding 
about the role of SSE and worker co-ops nowadays; second, I enquired about the relationship with the government and the articulation through public policies; third, I investigated the role of co-op as a point of resistance in the market economic context. Throughout these three areas of knowledge, I formulated an understanding of the role of this worker co-op and its position in relation with palliative and alternative poles. In total, 15 interviews, which totalled more than 22 hours of tape recordings, were conducted. I interviewed all the members of the co-op, some of whom also perform other roles in the administrative council or in other related organisations, such as Federación Red Grafica Cooperativa (Cooperative Graphic Network Federation and Federación de Cooperativas de Trabajo de la República Argentina, FECOOTRA (Argentinean Federation of Worker Cooperatives). Having presented the methodology, the next sections uncovers the existence of hegemonic and counter-hegemonic elements in the discourse of C-coop-Arg.

\section{Clash of discourses: the case of C-coop-Arg}

\subsection{Introducing C-coop-Arg}

C-coop-Arg is a printing worker cooperative founded in 2010 by a group of young professionals, who had taken part in other cooperatives before. This put them in contact with ERTs and alternative understandings of labour relationships. Although it is not an ERT, related to the type of ERTs that emerged in recent years (Ruggeri and Vieta, 2015), it can be conceptualised as part of the third era as it shares some features: it is a service-provider cooperative and located in the Buenos Aires metropolitan area. It has three productive departments: printing, media and design, accounts for 12 workers, and a singular characteristic is that all of them are young, between 21 and 35 years-old.

In its origins, C-coop-Arg received funding through the Programa de trabajo autogestionado (Selfmanaged work programme). It was a small amount of money, roughly 100 EUR per person per month, for one year in order to help them establish the co-op. As it was pointed out by Dinerstein (2007), the policy was considered successful regarding the support it provided for the start-up and consolidation of cooperatives, the control that the state was able to generate over them, and the cooptation of social movements. Moreover, this was one of the programmes that institutionalised socio-productive policies through including vulnerable population into labour market, and questioning passive recipients of public assistance (Hopp, 2011). Moreover, C-coop-Arg has applied for other government loans that have been used to buy machinery. Although it has not recently received public funding directly, intermediary organisations used to support SSE with public funding. For instance, it is paying back some loans they have already received from FECOOTRA, which ultimately is also public funding. Nonetheless, the change in government that occurred in November 2015, leading Mauricio Macri's centre-right Cambiemos coalition, seems to be a turning point for these policies and the availability of this funding. Moreover, although these policies succeeded in institutionalising social movements, their concern about Marci's neoliberal policies and the impact it might produce in the SSE sector and cooperatives in particular is significant. 
Moreover, C-coop-Arg also participated in the Microcredit programme of the Buenos Aires City government. The policy funded micro-productive businesses that generally would not be eligible for private funding. It was a structured microcredit network, based on a pyramidal model: the government provided the economic resources, a group of grassroots organisations were in charge of allocating and managing the credits, and recipients were the base of the triangle. C-coop-Arg played the role of mediator, allocating and supervising the credits, working in partnership with the local government and facilitating the development of the policy. The programme lasted for one year and finished in 2015.

Furthermore, another element that makes C-coop-Arg stand out is that it is part of the Cooperative Graphic Network Federation. The Graphic Network was established in 2003 based on informal relations among print cooperatives that belonged to the National Movement of Recuperated Enterprises, MNER. It was inspired by the success of two well-known international networking experiences: Mondragón Corporación Cooperativa, a network of financial, industrial, and service provider cooperatives based in the Basque Country (Azevedo and Gitahy, 2010), and Legacoop, the Italian network of agricultural, housing, consumer co-ops among others (Smith, 2001). Whereas Mondragón, according to Smith (2001), is more inclined towards a commercial objective, and Legacoop is focused on political and public representation, the aim of the Graphic Network merges both objectives ${ }^{4}$.

The Graphic Network currently consists of 21 cooperative-members and nine related ones, which employ more than 800 workers. Most of them are based in the Buenos Aires metropolitan area. It is a productive and economic organisation that aims to ensure competitiveness and the economic and social sustainability of its members (Raffaelli, 2013; 2015). Moreover, it has developed a combined commercial structure in which co-ops of the network perform as a single organisation, which allows them to increase production and provide services that they cannot do on their own, and therefore generate greater economic turnovers (Pacenza and Raffaelli, 2012). Moreover, the Network is also linked to national associations, such as FECOOTRA and the Instituto Nacional de Asociativismo y Economia Social, INAES (National Council of Associations and Social Economy) and international associations such as the International Cooperative Alliance (ICA) for the Americas.

\subsection{Contradiction of discourses in the worker cooperative}

The analysis of the discourses was based on the thesis that, because of the historical account of the cooperative as a reactionary movement, cooperatives are organisations that reproduce counterhegemonic practices in opposition to the hegemonic neoliberal discourse. In this sense, I aspire to reveal to what extent C-coop-Arg has been permeated by the neoliberal discourse and serves its

4 In a previous study (Raffaelli, 2015) details the economic and social benefits that worker cooperatives gain from being associated in a federation. 
interest rather than the interest of the cooperative. Consistent with CDA, I propose the co-op is an intermediary organisation, located in the social practice level, below the level of social structure, and C-coop-Arg discourses are determined in greater extent by the social structure. Contradicting the way in which cooperatives are conceptualised in large parts of the literature, as ideal types that perform one or the other discourse, this paper shows that both discourses coexist within the organisations. The alternative pole is enacted in relation with the radical form of labour, not based on the capitalist distinction between employees and employers, and a different form of economy, not focusing on profit maximisation, but taking into account social justice. For this reason it is understood as part of a counter-hegemonic discourse and linked with the historical radical roots of cooperatives. On the other hand, the ameliorated or palliative pole is enacted by those practices that reproduce the hegemonic neoliberal discourse. These practices are anchored in some members' mindset that correspond with for-profit companies, which is difficult to eradicate. Additionally, the idea that co-ops are a second option when the market economy cannot provide employment remains widespread and common. Furthermore, the populist feature of SSE discourages the challenging radical aspects of worker co-ops. These features are linked with the dominant for-profit neoliberal ideology, which in some cases is reproduced by members of C-coop-Arg. In this sense, the discursive practice of C-coop-Arg merges the counter-hegemonic discourse of the cooperative movement based on the radical roots of the movement, referred to as the alternative discourse, and the hegemonic discourse of neoliberalism, referred to as the palliative discourse.

One of the principal anchorages of the alternative discourse is the personal level, and it is in relation with the motivations for involvement in the co-op. Many members of C-coop-Arg have strong standpoints that led them to decide to work for a cooperative, which go far beyond wages and duties, as this quote reveals: "I am one of those who joined the co-op for ideological reasons, to make the world we want to get". They genuinely believe that they have to act themselves in order to change the reality in which they live. The co-op was built up on the basis of counter-hegemonic economic principles, and many members are also involved with other type of organisations that challenge mainstream economy and politics, such as consumer co-ops, underground media and voluntary organisations, as this quote reveals: "All this is linked with the world where my life is developed. I work here, but also in a cooperative magazine and a co-op radio". In this way, for many members, there is an individual commitment with an alternative understanding of the role of the economy and social relations, which led them to become involved in a cooperative.

Members of C-coop-Arg consider that SSE, and co-ops as part of it, should propose a different economy, and pursue a just society, as this quote shows: "We, as workers, should become subjects of social and political life in order to transform it, not merely agents. I reckon SSE is instrumental for that. (...) The co-op movement has to move along to a plural socio-political movement of the SSE". In order to build-up this "other economy", the articulation of different organisations of the SSE is instrumental, along with a strong cooperative movement. "All of us work here because we want a different life. The aim of the co-op is to give something different to its members. In order to do this, we have to be integrated in institutions in which we work for. There is a collective political work in which the co-op is 
only one organisation, and where members have to take an active role and participate actively". Thus, C-coop-Arg has established a strong articulation with FECOOTRA and the Graphic Network, along with the worker-cooperatives that form this latter organisation. In this way, these articulations are both horizontal and vertical. An example of this double articulation, members of C-coop-Arg have been involved in the process of taking over companies and work collaboratively in productive projects with other cooperatives that are part of the Graphic Network. In summary, they pursue a different economy, supported in a collective project, that articulates organisations of the SSE both horizontally and vertically.

Finally, in order to build this "other economy", alternative labour relations occupy the centre of C-coop-Arg, anchored in the management and organisational form in which the co-op is formed of daily. They understand that a more equal society is not possible within a market economy, and as a consequence, they prefer to be part of a diverse form of labour relationships, based on cooperation, self-management and autonomy. Small differences in payment among members according to their qualifications, flat management structure, and collective decision-making processes are all forms of an alternative labour relationship. It is in this point that the economic aims of the co-op chimes with the social, as this quote shows: "Political and productive decisions condition each other, in my view. We attempt to be part of a productive process based on solidarity". Moreover, C-coop-Arg shows that although all its members have grown up within the context of a neoliberal mindset in Argentina, they decided to set up a venture based on alternative labour relationships in which they can express themselves and be taken into account.

On the other hand, the palliative discourse is also present in the cooperative. Reproduction of the hegemonic discourse is also present at the individual level. Many of C-coop-Arg members have previously worked for for-profit companies and absorbed their rationality, which has deeply shaped their subjectivity as workers. "Employment labour relationships have deeply shaped us and many people couldn't get used to this way of working. We were used to being passive workers". They are well aware of the risk that these practices might have for the cooperative, as this quote shows: "We have to break those social relations that operate within co-ops which respond to an opposite economic rationality, otherwise we are undermining the movement ourselves". Moreover, another element that reproduces hegemonic economic discourse is the assumption that cooperatives are a second employment option when it is not provided by the for-profit sector. The belief that working for a cooperative is "better than nothing" reproduces and accepts the external understanding of co-ops imposed by the hegemonic discourse, rather than challenging it.

The involvement of C-coop-Arg in the Microcredit programme can also be conceptualised as an element that responds to a hegemonic discourse. Since the beginning, the policy was believed, "from above", only to serve the purpose of assisting those worst-off with a small amount of money. Although the policy was palliative in its origin and seen as "a way to fill the gap" in order to reduce poverty, C-coop-Arg decided to play the intermediary role between the government and people. The ultimate intention of C-coop-Arg was to support small businesses and, in the long run, persuade them to set up a co-op. However, they acknowledge that through the policy, 
it was not possible to change the beneficiaries' mindset of understanding economy differently, as "the idea of assistance and benefits is deeply embedded in those neighbourhoods". "Co-operativism is being used, not in negative terms... but just for solving the chaos that neoliberalism left out", said one member. The policy, therefore, was a strategy to formalise informal work through dolling out social assistance. Moreover, this use of cooperatives discourages the radical aspects of the sector and is functional to hegemonic interests. For this reason, it is considered as a palliative action taken by C-coop-Arg.

A final element of the palliative discourse of C-coop-Arg is given by the acceptance of the populist SSE. Although many policies were focused on socio-productive projects, and particularly on co-ops, a comprehensive study of this by Dinerstein (2007) presents insights about work-forwelfare programmes lacking in adequate training regarding complex issues such as self-management and cooperative values. Following this criticism, Ruggeri and Vieta (2015) stated that in some cases these policies merged SSE organisations into the state sphere and constrained their independence and autonomy. From the cooperatives' point of view, they recognise and are pleased by the fact that there are many policies that have SSE as a focus, despite the fact that they are not based on co-ops principles. Here, SSE organisations have been tempted to ask for policies that change the situation, without recognising that they ask it of the same actor that does not fully acknowledge their SSE values and practices, as this quote explains: "There are many policies, but government is not generating cooperative activists. SSE is just serving as socio-economic contention". These, again, reproduce hegemonic economic principles rather than the alternative view of "another economy" and allows the de-radicalisation of SSE standpoints.

In sum, the two discourses are present at different levels of analysis. On the one hand, the radical discourse is present in C-coop-Arg and challenges hegemonic neoliberal discourse. Participants state that they have joined the co-op because they believe another form of economy is possible. They practice "another economy", taking into account social justice issues and cooperative values and practices daily in the cooperative. Moreover, they put in practice alternative labour relationships that challenge the capitalist forms, practicing equality among members and participative governance. Finally, C-coop-Arg has strong horizontal and vertical links with other SSE organisations. Conversely, the palliative discourse is enacted in those practices in which neoliberal hegemony is not contested. Members of C-coop-Arg still recognise SSE as a second option for employment after the for-profit sector. In the case of the Microcredit Programme, although C-coop-Arg was motivated by the intention of persuading people in favour of cooperatives, it participated in a programme focused on alleviating neoliberal consequences. Instead of contesting the utilisation of SSE for this purpose, this is an insight of the general acceptance of the role allocated to the SSE in the hegemonic discourse. Finally, the populist understanding of the SSE provokes a paradoxical relationship between the government and the sector. Co-ops do not challenge the constrained limits that the state sets for them and, contradictorily, they ask for policies that take their values comprehensively into account. 


\section{Discussion and conclusion}

What sense can we make of these findings? Firstly, the fieldwork shows that the two discourses identified in the literature are present and intertwined in C-coop-Arg, challenging the incompatible theorisation presented in the introduction. While some authors consider SSE part of the current economic structure, as social service provider or re-including excluded populations in the market economy (Kaufmann, 1991), others understand it as a way to challenge an unfair social order (Laville, 1996; Amin, 1999; 2009). Cooperatives in Argentina, particularly those affected by the taking over process, my research suggests, have traces of palliative and radical alternatives to the market economy, and these discourses clash one against the other within the organisation. Co-ops are complex organisations, and therefore, it is not possible to present them as single-closed entities with no contradictions.

Regarding the particularities of the country, the re-appearance of the SSE in Argentina via movements such as the ERTs and related cooperative experiments that have emerged in recent years show how those most affected by economic crisis rejected the hegemonic idea that there is no alternative to neoliberalism. Rather, they put into practice an alternative solution on their own, attempting solidarity-based experiments that sought out an answer for the most direct effects of neoliberal crisis. Neoliberal discourse pushes out alternative socio-economic discourses. Hence, discovering that other forms of economic organisation and activity are possible challenges hegemony and the so-called "stability" imposed by the market economy. Therefore, SSE reveals other ways to commercialise, trade, produce, establish labour relationships, and more deeply, proves that other rationalities that go further than profit maximisation and include individuals are possible.

However, it is important to take into consideration that a narrow understanding of SSE might lead us to a misleading analysis. On the one hand, SSE ventures should thrive as an alternative to capitalism operating within a for-profit market context, which is contradictory at first glance as this means that SSE organisations should accept market competition in order to be able to sustain the co-op economically. On the other hand, SSE political activism decreased during the 20th century up to the point of being theorised as non-political, and it increased dramatically post-2001 in Argentina, as the neoliberal crisis made collective response almost the unique option for those experiencing needs. Therefore, the separation of the social, economic and political elements in the neoliberal discourse has led to a narrow understanding of the potentials this economic sector might bring to the whole society (McMurtry, 2004). For instance, SSE organisations can act as agents of social transformation, cultural resistance, and emancipatory alternatives. Moreover, they are driven by social justice values, inclined towards sustainable modes of production (Mellor, 1997), and empowering disadvantaged communities through democratic social relationships (Amin, 1999). Finally, they are democratic organisations that build up counter-hegemonic identities; they propose new forms of social relations and governance. Not understanding the SSE in all its complexity is part of accepting the hegemonic discourse and the lack of alternative. 
Considering this discussion, SSE is a field of disagreements and tensions in a variety of forms. In academic terms, definitions of SSE are diverse and, to some extent, incommensurable. Moreover, governments across the world have shown different interests and have lent different support to the SSE. Thus, this clearly shows SSE is a contested field, for which a holistic understanding is required. This paper is an outline of the dichotomy that is found in the literature and as illustrated in the Argentinean co-op case, but it does not aim to finish the discussion. More research is needed in order to know whether this is a particular phenomenon of this case or the coexistence of two contradictory discourses is a consequence of market and state imperatives compromising co-ops' ideals. However, the polar division that appears in the theory does not correspond with practice. SSE organisations are not entirely radical nor palliative; these two discourses are mixed up within organisations. Moreover, given that they do not exist independently of the market economy, they are transversed by the hegemonic neoliberal definition of the SSE. Paradoxically within this constricted framework, SSE propose itself as an alternative for change and members of SSE organisations are truly convinced that it proposes an alternative to the current economic system. Encouraging this space of resistance is fundamental in the construction of another economy.

\section{References}

Adelman, J. (1992). Socialism and Democracy in Argentina in the Age of the Second International, Hispanic American Historical Review, 72(2): 211-238. DOI: https://doi.org/10.2307/2515555

Aiken, M. (2006). Towards market or state? Tensions and opportunities in the evolutionary path of three UK social enterprises. In: M. Nyssens (Ed.), Social Enterprises in Europe: between market, public policies and communities. London: Routledge.

Allahdadi, F. (2011). The contribution of agricultural cooperatives on poverty reduction: a case study of Marvdasht, Iran, Journal of American Science, 7(4): 22-25.

Amin, A. (1999). An institutionalist perspective on regional economic development, International Journal of Urban and Regional Research, 23(2): 365-378. DOI: https://doi.org/10.1111/1468-2427.00201

Amin, A., Cameron, A. \& Hudson, R. (2002). Placing the social economy. London: Routledge.

Amin, A. (2009). Extraordinarily ordinary: working in the social economy, Social Enterprise Journal, 5(1): 30-49. DOI: https://doi.org/10.1108/17508610910956390

Albuquerque, P. (2004a). Asociativismo. In: D. Cattanni (Org.), La otra economía. Buenos Aires: Altamira.

Albuquerque, P. (2004b). Autogestión. In: D. Cattanni (Org.), La otra economía. Buenos Aires: Altamira.

Anheier, H.K. (2004). The third sector in Europe: Five theses. New York: Springer.

Arzadun, P. (2011). Globalización económica y cooperativismo. Estudio empírico sobre el sector cooperativo argentino, Revista de Economía Pública, Social y Cooperativa, 72: 215-235. CIRIEC-España.

Atzeni, M. \& Vieta, M. (2014). Between class and the market: Self-management in theory and in the practice of workerrecuperated enterprises in Argentina. In: M. Parker, G. Cheney, V. Fournier, \& C. Land (Eds.), The Routledge companion to alternative organization. London: Routledge, pp. 47-63.

Atzeni, M., \& Ghigliani, P. (2007). Labour process and decision-making in factories under workers' self-management: empirical evidence from Argentina, Work, Employment \& Society, 21(4): 653-671. DOI: https://doi. org/10.1177/0950017007082875 
Azevedo, A. \& Gitahy, L. (2010). The co-operative movement, self-management, and competitiveness: the case of Mondragón Corporation, WorkingUSA: The Journal of Labor and Society, 13: 5-29.

Beccaria, L. \& Mauricio, R. (2005). Mercado de Trabajo y equidad en la Argentina. Buenos Aires: Ed. Prometeo /UNGS.

Benson, T. (2014). Building good management practices in Ethiopian agricultural cooperatives through regular financial audits, Journal of Co-operative Organization and Management, 2(2): 72-82. DOI: https://doi.org/10.1016/j. jcom.2014.10.001

Belsey, C. (2002). Post-structuralism. A very short introduction. New York: Oxford University Press. DOI: https://doi. org/10.1093/actrade/9780192801807.001.0001

Brenner, N., Peck, J. \& Theodore, N. (2010). Variegated neoliberalization: geographies, modalities, pathways, Global networks, 10(2): 182-222. DOI: https://doi.org/10.1111/j.1471-0374.2009.00277.x

Brooks, S., Leach, M., Millstone, E. \& Lucas, H. (2009). Silver bullets, grand challenges and the new philanthropy, STEPS Working Paper n. 24, University of Sussex.

Campetella, A., González Bombal, I. \& Roitter, M. (2000). Definiendo el sector sin fines de lucro en Argentina. Buenos Aires: CEDES y John Hopkins University.

Conniff, M.L. (Ed.) (2012). Populism in Latin America, Second Edition, Tuscaloosa: The University of Alabama Press. Project MUSE. Available online at: https://muse.jhu.edu/book/22550 [Accessed on: 25 March 2015].

Coraggio, J.L. (2002). La economía social como vía para otro desarrollo social. De la emergencia a la estrategia: más allá del alivio de la pobreza. Available at: http://www.coraggioeconomia.org/jlc/archivos\%20para\%20descargar/La\%20 Economia\%20Social\%20como\%20alternativa\%20estructural\%204.pdf . [Accessed on: 18 July 2016].

Coraggio, J.L. (2004). La gente o el capital. Desarrollo local y economía del Trabajo. Buenos Aires: Espacio Editorial.

Coraggio, J.L. (2007). La economía social y la búsqueda de un programa socialista para el siglo XXI, Revista Foro, Los socialismos del Siglo XXI, Opciones en debate, 62: 37-54.

Coraggio, J.L. (2010). Economía Social y Solidaria. Portal de Economía Solidaria. Available at:

http://www.economiasolidaria.org/documentos/economia_social_y_solidaria_jose_luis_coraggio [Accessed on: 17 July 2014.]

Coraggio, J.L. (2011). La presencia de la economía social y solidaria (ESS) y su institucionalización en America Latina. Estados Generales de la Economía Social y Solidaria, 17-19 junio 2011, París.

Coraggio, J.L. (2015). Institutionalising the social and solidarity economy in Latin America. In: P. Utting (Ed.), Social and Solidarity Economy. Beyond the fringe, UNRISD. London: Zed Books, pp. 130-149.

Cvejic, S. \& Petrovic, I. (2015). Social and political embeddedness of Argentina's worker- recuperated enterprises: a brief history and current trends, Euricse Working Papers, 80/15. Trento: Euricse. Available at: http://www.euricse.eu/ wp-content/uploads/2015/09/WP-80_15_Petrovic-Cvejic.pdf [Accessed on: 25 April 2016]

Dinerstein, A.C. \& Neary, M. (Eds.) (2002). The Labour Debate: An Investigation into the Theory and Reality of Capitalist Work. Ashgate: Aldershot-Burlington.

Dinerstein, A.C. (2007). Workers' factory takeovers and new state policies in Argentina: Towards an "institutionalisation" of non-governmental public action, Policy \& Politics, 35(3): 529-550. DOI: https://doi. org/10.1332/030557307781571641

Dinerstein, A.C. (forthcoming). Co-construction or prefiguration? Rethinking the "translation" of SSE practices into policy. In: P. North \& M. Scott Cato (Eds.), Towards Just and Sustainable Economies: the Social and Solidarity Economy North and South. University of Bristol: Policy Press.

Dol, J. \& Odame, H.H. (2013). Stitching toward empowerment: A case study of Tabiro Ladies' Club, Journal of Cooperative Organization and Management, 1(2): 70-80. DOI: https://doi.org/10.1016/j.jcom.2013.10.005

Eme, B. \& Laville, J.L. (2004). L'économie solidaire ou l'économie comme écologie sociale, Ecologie \& politique, (1): $13-25$. 
Fairclough, N. (2003). Analyzing Discourse: Textual Analysis for Social Research. London: Routledge

Fontela, E. (2008). Cooperativas que recuperan Empresas. Documento de Trabajo No 205, Universidad de Belgrano. Available at: http://184.168.109.199:8080/xmlui/bitstream/handle/123456789/474/205_fontenla.pdf?sequence=2 [Accessed on: 2 December 2012].

Foschiatto, P. \& Stumpo, G. (2006). Políticas municipales de microcrédito: un instrumento para la dinamización de los sistemas productivos locales: estudios de caso en América Latina, Libros de la CEPAL, Vol. 89.

Gibson-Graham, J.K. (2008). Diverse economies: performative practices for other worlds, Progress in Human Geography, 32(5): 613-632. DOI: https://doi.org/10.1177/0309132508090821

Giovannini, M. \& Vieta, M. (forthcoming). Co-operatives in Latin America. In: J. Michie, J. Blasi \& C. Borzaga (Eds.), The Handbook of Co-operative and Mutual Businesses. Oxford, UK: Oxford University Press.

Hopp, M.V. (2011). Relación Estado-sociedad civil en las políticas de desarrollo socio-productivo en Argentina contemporánea, Revista Katálysis, 14(1): 13-22.

ICA (1995). International Cooperative Alliance Statement of the co-operative identity. Available at: http://ica.coop/en/ whats-co-op/co-operative-identity-values-principles [Accessed on: 25 April 2016].

Jick, T. (1979). Mixing qualitative and quantitative methods: triangulation in action, Administrative Science Quarterly, 24(4): 602-611. DOI: https://doi.org/10.2307/2392366

Jørgensen, M. \& Phillips, L. (2002). Discourse Analysis as Theory and Method. London: SAGE Publications Ltd. DOI: https://doi.org/10.4135/9781849208871

Kaufmann, F.X. (1991). The blurring of the distinction "state v. society" in the welfare state. In: F.X. Kaufmann (Ed.), The Public Sector-Challenge for Coordination and Learning. Berlin: De Gruyter, pp. 152-164. DOI: https://doi. org/10.1515/9783110857016-009

Kendall, J. (2005). The third sector and the policy process in the UK: ingredients in a hyper-active horizontal policy environment. London: London School of Economics and Political Science, LSE Library.

Laville, J.L. (1996). Economy and solidarity: exploring the issues. Reconciling Economy and Society: Towards a Plural Economy. Paris: Organisation for Economic Cooperation and Development (OECD).

Laville, J.L. (2013). Social and solidarity economy: A theoretical and plural framework. UNRISD conference: Potential limits of social and solidarity economy, 6-8 May 2013, Geneva.

Laville, J.L., Young, D.R. \& Eynaud, P. (Eds.) (2015). Civil Society, the Third Sector and Social Enterprise: Governance and Democracy. New York: Routledge.

Levín, A. \& Verbeke, G. (1997). El cooperativismo argentino en cifras: tendencias en su evolución: 1927-1997. Buenos Aires: Universidad de Buenos Aires, Facultad de Ciencias Económicas.

Lima, J. (2004). O Trabalho Autogestionário em Cooperativas de Produção: O Paradigma Revisitado, Revista Brasileira de Ciências Sociais, 19(56): 45-62. DOI: https://doi.org/10.1590/S0102-69092004000300004

Lindemboin, J., Graña, J. M. \& Kennedy, D. (2005). Distribución funcional del ingreso en Argentina. Ayer y hoy, Documentos de trabajo n. 4. CEPED, Universidad de Buenos Aires. Available at: http://biblioteca.clacso.edu.ar/ ar/libros/argentina/ceped/cua4.pdf [Accessed on: 9 September 2014].

Maldovan Bonelli, J. (2014). De la autonomía a la asociatividad: la organización del trabajo cartonero "en calle" en cooperativas de la Ciudad Autónoma de Buenos Aires, Revista del Centro de Estudios de Sociología del Trabajo (CESOT), n. 6.

Mano, V., Raffaelli, P. \& Souza, R. (2016). Discursive practices and neoliberal ideology in developing countries: The case of Argentina, Brazil and Macedonia, University of Roehampton working paper.

McMurtry, J.J. (2004). Social economy as political practice, International Journal of Social Economics, 31(9): 868-878. DOI: https://doi.org/10.1108/03068290410550656

McMurtry, J.J. (2009). Living economics. Emond Montgomery Publications. 
Mellor, M. (1997). Women, nature and the social construction of "economic man", Ecological Economics, 20(2): 129140. DOI: https://doi.org/10.1016/S0921-8009(95)00100-X

Molloy, A., McFeely, C. \& Connolly, E. (1999). Building a social economy for the new millennium. Derry: Guildhall Press/ NICDA.

Montes, V.L. \& Ressel, A.B. (2003). Presencia del cooperativismo en Argentina, Revista UniRcoop, 1.

Moulaert, F. \& Ailenei, O. (2005). Social economy, third sector and solidarity relations: a conceptual synthesis from history to present, Urban studies, 42(11): 2037-2053. DOI: https://doi.org/10.1080/00420980500279794

Moulaert, F. \& Nussbaumer, J. (2005). Defining the social economy and its governance at the neighbourhood level: a methodological reflection, Urban Studies, 42(11): 2071-2088. DOI: https://doi.org/10.1080/420980500279752

Murmis, M. \& Portantiero, J.C. (2004). Orígenes del peronismo (edición definitiva). Buenos Aires: Siglo XXI.

Murray, U. (2013). To what extent is the voluntary sector colonised by neo-liberal thinking. In: Proceedings of the XIII international critical management conference: extending the limits of neo-liberal capitalism, University of Manchester, pp. 10-12.

Neffa, J., Brown, B. \& López, E. (2012). Políticas activas de empleo durante la posconvertibilidad, Empleo, desempleo y políticas de empleo, n. 11.

Nickel, P.M. \& Eikenberry, A.M. (2010). Philanthropy in an era of global governance, In: R. Taylor (Ed.), Third sector research. New York: Springer, pp. 269-279. DOI: https://doi.org/10.1007/978-1-4419-5707-8_19

North, P. \& Huber, U. (2004). Alternative spaces of the "Argentinazo", Antipode, 36(5): 963-984. DOI: https://doi. org/10.1111/j.1467-8330.2004.00463.x

Nyssens, M. (2006). Social enterprise. At the crossroads of market, public policies and civil society. London and New York: Routledge.

Pacenza, S. \& Raffaelli, P. (2012). Asociando cooperativas. De las unidades economics a las redes de organizaciones. El paso de la Red Gráfica Cooperativa. In: Ralón, G. (Ed.), Condiciones y medio ambiente de trabajo, perspectivas de desarrollo en America Latina. Buenos Aires: ACILTRHA.

Pearce, J. (2005). Social enterprise in Anytown. London: Calouste Gulbenkian Foundation.

Raffaelli, P. (2013). Modalidades de gestión organizacional en cooperativas de trabajo pertenecientes a la Federación Red Gráfica Cooperativa. Tesis de Maestría en Ciencias Sociales del Trabajo UBA-CEIL PIETTE. Available at: http:// www.ceil-conicet.gov.ar/formacion/maestria-en-ciencias-sociales-del-trabajo-uba/ [Accessed on: 25 May 2016].

Raffaelli, P. (2015). Joining workers' co-operatives. The case of the Argentine Co-operative Graphic Network Federation, International Review of Co-operation, Youth Scholars special edition. Issue 2014: 64-75. Available at: http://ccr. ica.coop/sites/ccr.ica.coop/files/attachments/InternationalCoopReview2014\%20(00000002)_for\%20web.pdf [Accessed on: 25 May 2016].

Ranis, P. (2010). Argentine Worker Cooperatives in Civil Society: A Challenge to Capital-labor Relations, WorkingUSA, 13(1): 77-105. DOI: https://doi.org/10.1111/j.1743-4580.2010.00273.x

Razeto, L. (1984). Economía de solidaridad y mercado democrático: Libro primero, La economía de donaciones y el sector solidario. Programa de Economía del Trabajo. Academia de Humanismo Cristiano.

Rebón, J. \& Caruso, L. (2004). Desobedeciendo al desempleo: la experiencia de las empresas recuperadas (No. 2). Ediciones P. ica. so/La Rosa Blindada.

Ressel, A.B., Silva, N.C. (2008). Estudio de las cooperativas agrarias en Argentina. In: Cooperativas e integración regional. La trayectoria de las cooperativas agropecuarias y de ahorro y crédito en el MERCOSUR. Instituto de Estudios Cooperativos, Facultad de Ciencias Económicas, Universidad Nacional de La Plata, Argentina.

Restakis, J. (2010). Humanizing the Economy: Co-operatives in the Age of Capital. New Society Publishers.

Ruggeri, A. (2011). Reflexiones sobre la autogestión en las empresas recuperadas argentinas, Estudios. Revista de Pensamiento Libertario, (1): 60-79. 
Ruggeri, A. \& Vieta, M. (2015). Argentina's Worker-Recuperated Enterprises, 2010-2013: A Synthesis of Recent Empirical Findings, Journal of Entrepreneurial and Organizational Diversity, 4(1): 75-103. DOI: https://doi. org/10.5947/jeod.2015.005

Saavedra, L. (2003). La dinámica del trabajo desde la perspectiva de las empresas recuperadas y autoorganizadas por los trabajadores, Laboratorio on line, 5(13): 31-37.

Salamon, L.M. \& Anheier, H.K. (1997). Defining the nonprofit sector: A cross-national analysis. Manchester University Press.

Schujman, L. (1984). El cooperativismo en la Argentina, Estudios cooperativos, (52): 125-136.

Shenton, A.K. \& Hayter, S. (2004). Strategies for gaining access to organisations and informants in qualitative studies, Education for Information, 22(3-4): 223-231.

Smith, M.J. (2010). From big government to big society: changing the state-society balance, Parliamentary Affairs, 63(4): 818-833. DOI: https://doi.org/10.1093/pa/gsq023

Smith, S. (2001). Blooming together or wilting alone? Network externalities and Mondragón and La Lega co-operative networks, WIDER Discussion Papers, n. 2001/27. World Institute for Development Economics (UNU-WIDER).

Spear, R. (2005). Impact of the third sector in Europe. In: C. Tsuzuki, N. Hijikata \& A. Kurimoto (Eds.), The emergence of Global Citizenship: Utopian ideas, Cooperatives movements and the Third Sector. New Delhi: Robert Owen Association of Japan.

Teitelbaum, V. (2011). El mutualismo en el mundo del trabajo (Tucumán, Argentina, 1877-1914), Varia Historia, 27(46): 665-688.

UN (2006). The Millennium Development Goals Report. United Nations. Available at: https://www.un.org/zh/ millenniumgoals/pdf/MDGReport2006.pdf [Accessed on: 17 February 2014].

Utting, P. (Ed.). (2015). Social and solidarity economy: beyond the fringe. UNSRID. London: Zed Books.

Vieta, M. (2012). From Managed Employees to Self-Managed Workers: Transformations of Labour at Argentina's Worker-Recuperated Enterprises. In: M. Atzeni (Ed.), Alternative Work Organizations. Basingstoke, UK: Palgrave Macmillan, pp. 129-156. DOI: https://doi.org/10.1057/9781137029041_6

Vieta, M. (2013). The Emergence of the empresas recuperadas por sus trabajadores: A Political Economic and Sociological Appraisal of Two Decades of Self-management in Argentina, Euricse Working Papers, 55/13. Trento: Euricse. Available at: http://www.euricse.eu/wp-content/uploads/2015/03/1374060540_n2366.pdf [Accessed on: 25 May 2016].

Vieta, M. (2014). Learning in struggle: Argentina's new worker cooperatives as transformative learning organizations, Relations Industrielles/Industrial Relations, 69(1): 186-218.

Villar, A. (2004). Una década de desarrollo local en Argentina. Balance y perspectivas, Mundo Urbano, n. 24. Universidad Nacional de Quilmes, Argentina.

Vuotto, M. (2012). Acerca de las orientaciones del cooperativismo de trabajo: el caso argentine, Sociedade em Debate, 13(1): 101-120.

Wodak, R. \& Meyer, M. (Eds.) (2009). Methods for critical discourse analysis. Sage.

Wyczykier, G.S. (2007). De la dependencia a la autogestión laboral sobre la reconstrucción de experiencias colectivas de trabajo en la Argentina contemporanea. Tesis de Doctorado. FLACSO. Sede Académica Argentina, Buenos Aires. 